\author{
Akshay Khatri', Abhinav Agrawal ${ }^{2}$, Rutuja R. Sikachi' ${ }^{2}$, Dhruv Mehta ${ }^{3}$, Sonu Sahni ${ }^{4}$, Nikhil Meena ${ }^{5}$ \\ 'Department of Medicine, Westchester Medical Center, Valhalla, New York, USA \\ ${ }^{2}$ Division of Pulmonary, Critical Care \& Sleep Medicine, Northwell Health - Zucker School of Medicine at Hofstra/Northwell, \\ New Hyde Park, New York, USA \\ ${ }^{3}$ Division of Gastroenterology, Westchester Medical Center, Valhalla, New York, USA \\ ${ }^{4}$ Touro College of Osteopathic Medicine, Department of Primary Care, Harlem, New York, USA \\ ${ }^{5}$ Division of Pulmonary, Critical Care \& Sleep Medicine, University of Arkansas, Little Rock, USA
}

\title{
Inflammatory myofibroblastic tumor of the lung
}

The authors declare no financial disclosure

\begin{abstract}
Inflammatory myofibroblastic tumors (IMT) of the lung, first reported in 1939, are considered a subset of inflammatory pseudo -tumors. They are a distinctive lesions composed of myofibroblastic spindle cells accompanied by an inflammatory infiltrate of plasma cells, lymphocytes, and eosinophils. IMTs may be benign, invade surrounding structures, undergo malignant transformation, recur or may even metastasize. They can occur due to a genetic mutation or can occur secondary to infectious or autoimmune diseases. Patients may be asymptomatic, or present with cough, hemoptysis, dyspnea, pleuritic pain, constitutional symptoms or pneumonia. In this article we review the pathophysiology, genetics, clinical presentation, imaging findings of IMT of the lung. We also discuss the various surgical and non-surgical treatment options and the prognosis associated with this disease.
\end{abstract}

Key words: inflammatory myofibroblastic tumor of the lung (IMT), inflammatory pseudo-tumor (IPT), pulmonary neoplasm, ALK, bronchoscopy

Adv Respir Med. 2018; 86: 27-35

\section{Introduction}

Inflammatory pseudo-tumors (IPT) were first described in 1905, in the orbital tissues of four patients, with infiltration of the soft tissue with lymphocytes [1]. They were labeled as 'pseudo -tumors' because they clinically and radiologically mimicked malignancies [2]. Inflammatory myofibroblastic tumors (IMT) of the lung, first reported in 1939 [3], are considered a subset of these IPTs. They are a distinctive lesions composed of myofibroblastic spindle cells accompanied by an inflammatory infiltrate of plasma cells, lymphocytes, and eosinophils [4].

IMTs account for 0.04 to $0.1 \%$ of all pulmonary neoplasms $[5,6]$. They are more common in children and are the most common pediatric primary lung lesion [7, 8]. IMTs are usually benign and resection achieves complete cure. However, there are times when they invade surrounding structures, undergo malignant transformation, recur $[9,10]$ or may even metastasize $[11,12]$.

IMTs have been synonymously referred to as pseudo-sarcomatous myo-fibroblastic or fibromyxoid lesion, plasma cell granuloma, fibrous xanthoma, plasma cell pseudosarcoma, lymphoid hamartoma, myxoid hamartoma, omental mesenteric myxoid hamartoma, inflammatory myofibrohistiocytic proliferation, benign myofibroblastoma, and inflammatory fibrosarcoma [4, 9, 13].

\section{Pathophysiology and genetics}

The exact pathophysiology and mechanism of neoplasia in IMTs is unknown. Several genes and chromosomal abnormalities have been found

Address for correspondence: Abhinav Agrawal MD, Division of Pulmonary, Critical Care \& Sleep Medicine — Hofstra Northwell School of Medicine, New Hyde Park, NY 11040. Tel.: 516-465-5400, e-mail: Abhinav72@gmail.com, Aagrawal1@northwell.edu DOI: 10.5603/ARM.2018.0007

Received: 08.11.2017

Copyright (C) 2018 PTChP

ISSN 2451-4934 
to be associated with IMTs. Anaplastic Lymphoma Kinase (ALK) gene locus on 2p23 encodes a classical receptor tyrosine kinase (RTK) in mice and humans. An ALK rearrangement is discovered in approximately $40-50 \%$ of IMTs [14-17], but more commonly in younger population [18]. ALK rearrangements produce fusion proteins that constitutively activate tyrosine kinase, similar to its action in anaplastic large-cell lymphoma, diffuse large-cell lymphoma and non-small cell lung cancer (NSCLC) [18, 19]. As will be described later, the ALK-RTK can be a target for newer drug therapies.

ROS-1 is a receptor tyrosine kinase (RTK) of the insulin receptor family. Chromosomal rearrangements involving the ROS-1 gene, on chromosome $6 q 22$, were originally described in glioblastomas as well as non-small cell lung cancers (NSCLC) [20]. Some IMTs without ALK rearrangement (ALK-negative) demonstrate ROS-1 gene fusions. One study reported that 4/9 (44\%) of ALK-negative tumors had distinct ROS1 fusions [21]. There have been some rare cases of IMT that have been negative for ALK and ROS-1 mutations [22].

A subset of IMT lack ALK oncogenic activation but contain rearrangements targeting the HMGIC (also known as HMGA2) gene on chromosome 12q15. Chromosomal aberrations involving this region are very frequent among other benign tumors, such as lipomas, uterine leiomyomas, or pulmonary chondroid hamartoma [23]. There has been a significant association between translocations in IMT and a high rate of aneuploidy [24], the presence of which correlates well with local recurrence and more aggressive biologic behavior [13]. The presence of hyperdiploidy serves as an indicator of the neoplastic nature of IMTs. Derivative of Chromosome (Der9) was reported in one case of an omental-mesenteric IPT [25]. It was an extra chromosome that evolved from a translocation between the long arm of chromosome 2 and the short arm of chromosome $9[(2 ; 9)$ (q1, 3; p2, 2)]. Other mutations such as PDGFR- $\beta$ fusion have also been reported in some IMTs [21].

\section{Association with other diseases}

Multiple infections including pulmonary tuberculosis, pseudomonas lung infection, moraxella catarrhalis, actinomycetes, mycoplasma, mycobacteria, Epstein-Barr virus and human herpes virus 8 ( $H H V-8)$ have also been reported with IPTs [10, 26-40].

Patients with autoimmune conditions such as Sjörgen's syndrome have also been reported to have lung IMTs [41] and IPTs in choroid plexus [42], liver [43] and pancreas [44]. In one patient with lung IMT, concurrent B-cell lymphoma was seen [9]. IgG4 syndrome [45, 46] has been reported with IPTs; these tumors have been seen to form a subset of this syndrome. Pulmonary and extra-pulmonary IMTs have also been reported following hematopoietic stem cell [47-49], graft versus host disease [50] and solid-organ transplant [51-54].

\section{Classification}

The classification of IMTs is listed in Table 1.

\section{Clinical features}

They may be asymptomatic, or present with cough, hemoptysis, dyspnea and pleuritic pain $[5,56]$. Systemic symptoms such as fever, weight loss, malaise and fatigue can be seen in 15-30\% of patients. Some may present with recurrent pneumonias $[57,58]$.

\section{Imaging}

Pulmonary IMTs occur more frequently in the lower lobes with a predilection for peripheral lung parenchyma and sub-pleural locations [7, 59]. On chest radiographs, pulmonary IMTs appear as solitary, circumscribed, lobulated lesions preferentially localized to the lower lobes, occasionally with pleural effusions (Fig. 1) [56]. When IMT presents as a solitary pulmonary nodule, the main radiologic differential diagnosis includes a primary or secondary neoplasm, hamartoma, hemangioma, chondroma, and pulmonary sequestration [60, 61].

On computed tomographic (CT) scans, inflammatory pseudotumors have a variable and nonspecific appearance, but most commonly they appear with heterogeneous attenuation and enhancement (Fig. 2A-C). On T1-weighted magnetic resonance (MR) images, these tumors have intermediate signal intensity and high signal intensity on T2-weighted images [60]. Calcification within the lesion occurs more frequently in children than in adults (Fig. 2A, B). The pattern of calcification can range from an amorphous, mixed, or fine fleck-like pattern to heavy mineralization.

IMTs can be discovered bilaterally, with endobronchial lesions causing atelectasis and in the pulmonary arteries [60,62-64]. IMTs may show uptake of fluorodeoxyglucose; and it may be used to monitor response to therapy [62, 65, 66]. 


\section{Table 1. Classification of IMT's}

(A) Earliest classification by Cerfolio et al. [5]

\begin{tabular}{|c|c|c|}
\hline Non-invasive IPT & \multicolumn{2}{|l|}{ Invasive IPT } \\
\hline Asymptomatic patients & \multicolumn{2}{|c|}{ Younger patient with systemic symptoms of fever, fatigue, or weight loss } \\
\hline $\begin{array}{l}\text { Small lesions that do not invade surrounding } \\
\text { structures }\end{array}$ & \multicolumn{2}{|c|}{$\begin{array}{l}\text { It is large and may invade local mediastinal structures or the chest wall } \\
\text { Grossly, it is an invasive tumor that grows through tissue planes } \\
\text { Pathologically, it is characterized by nuclear atypia and a high number of mitotic figures }\end{array}$} \\
\hline Usually easily removed by wedge resection & \multicolumn{2}{|c|}{$\begin{array}{l}\text { Usually requires a lobectomy or pneumonectomy for complete removal and may also } \\
\text { require a concomitant chest wall resection }\end{array}$} \\
\hline \multicolumn{3}{|l|}{ (B) Classification by Matsubara et al. [55] } \\
\hline Organizing pneumonia & Fibrous histiocytoma & Lymphoplasmacytic \\
\hline $\begin{array}{l}\text { Intra-alveolar lymphohistiocytic inflammation } \\
\text { converting peripherally to intra-alveolar fibro- } \\
\text { sis and centrally to interstitial fibrosis (becau- } \\
\text { se of fibroblasts proliferation) }\end{array}$ & $\begin{array}{l}\text { Predominant spindle cell proliferation, histio- } \\
\text { cytes in a storiform pattern and loss of the } \\
\text { alveolar architecture }\end{array}$ & $\begin{array}{l}\text { Predominant lymphocytes and plasma } \\
\text { cells with little fibrosis }\end{array}$ \\
\hline \multicolumn{3}{|c|}{ (C) 3 basic variants of IMT [4] as per WHO classification of soft tissue tumors } \\
\hline Resembling nodular fasciitis & $\begin{array}{l}\text { Resembling fibrous histiocytoma or fibroma- } \\
\text { tosis }\end{array}$ & Resembling scar or desmoid tumor \\
\hline $\begin{array}{l}\text { Loosely organized myofibroblasts in an } \\
\text { edematous myxoid background with plasma } \\
\text { cells, lymphocytes, eosinophils, and blood } \\
\text { vessels }\end{array}$ & $\begin{array}{l}\text { Dense aggregates of spindle cells arrayed in } \\
\text { a variable myxoid and collagenized backgro- } \\
\text { und admixed with a distinctive inflammatory } \\
\text { infiltrate, diffuse clusters of plasma cells, and } \\
\text { lymphoid nodules }\end{array}$ & $\begin{array}{l}\text { Collagen sheets with scattered plasma } \\
\text { cells and eosinophils }\end{array}$ \\
\hline
\end{tabular}

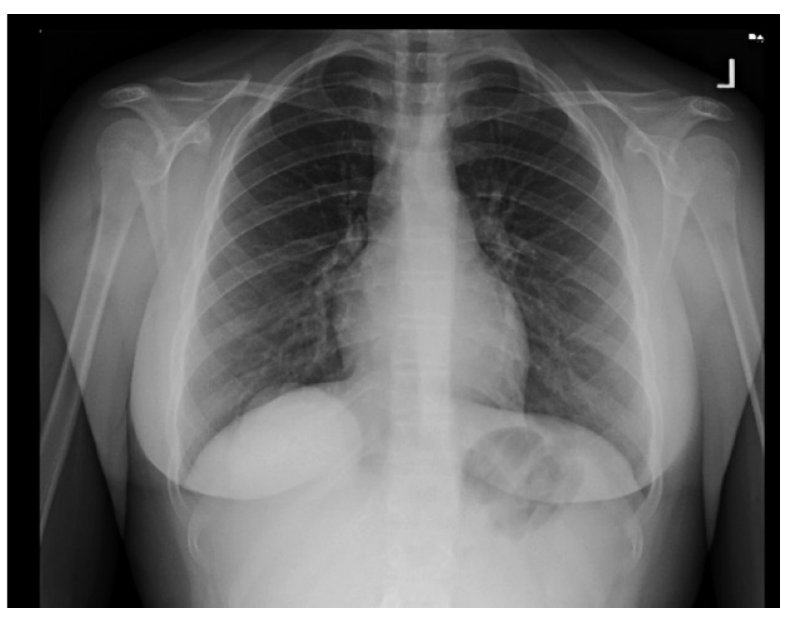

Figure 1. Chest $\mathrm{X}$-ray showing well circumscribed right lower lobe lesion

Interestingly, a positive uptake in 111 In-Diethylene triamine pentaacetic acid (DTPA)-D-Phe1 scan (Octreoscan) has been described implying response to somatostatin analogue receptors [67].

\section{Associated serum biochemistry and histopathology}

Laboratory evaluation may reveal microcytic anemia; increase in acute phase reactants such as erythrocyte sedimentation rate (ESR) and C-reactive protein (CRP); thrombocytosis and polyclonal hypergammaglobulinemia. These findings have been attributed to overproduction of interleukin (IL)-6 [39, 57, 68].

On biopsy, the predominant cells seen are spindle cells. They are seen as interlacing fascicles among a polymorphous inflammatory infiltrate consisting of mature plasma cells and small lymphocytes [10, 12]. Spindle cell proliferation is noted to be more marked in IMT, whereas lymphoplasmacytic infiltration is more prominent in IPTs [69]. An example of histopathology slides including immunohistochemistry from a patient with IMT is demonstrated in the attached figures (Fig. 3, 4A, B, 5-7]. On immunohistochemistry (IHC), virtually all IMTs show reactivity for vimentin. The reactivity for smooth muscle actin and muscle specific actin varies in pattern. Desmin and focal cytokeratin immunoreactivity is identified in some cases. Myogenin, myoglobin, and S100 protein are negative $[4,12]$.

ALK expression may be negative by IHC; rearrangement for ALK locus by fluorescence in situ hybridization (FISH) may be required [39] or newer IHC methods may have to be adopted [70]. Another difference between IPTs and IMTs is that on the basis of IHC and FISH characteri- 

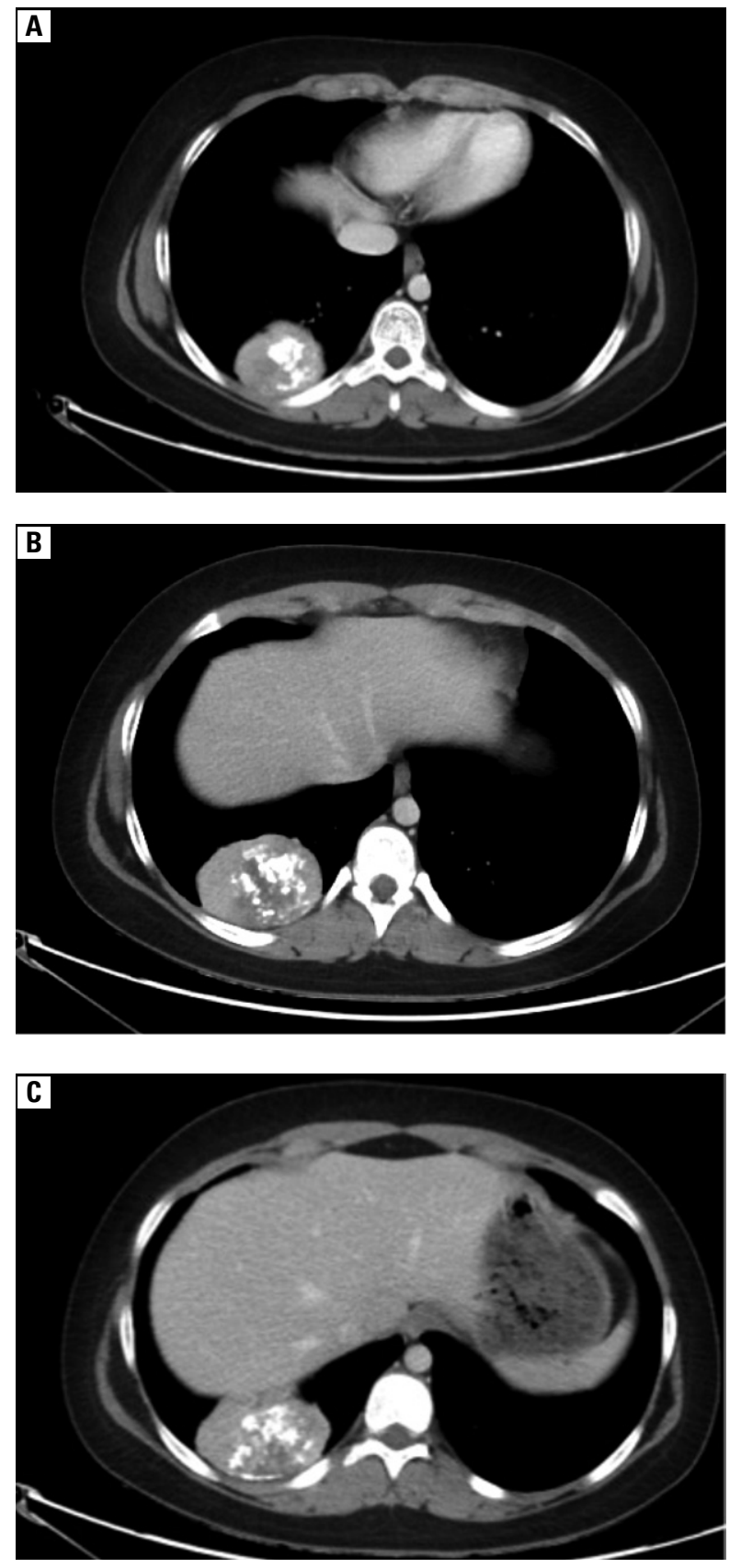

Figure 2A-C. Computed tomography of the chest showing a mass in the right lower lobe with interspersed calcification

stics, IMTs have not been found to always be IgG4 related [46]. As seen later, this fact may explain the response to steroids.

Prior to surgery, it is recommended to have liver function testing, pulmonary function testing and staging CT scans of the chest and upper abdomen. This helps to evaluate for concurrent IPTs/IMTs in other parts of the body [5]. Since morphological features do not predict biologic behavior, and the ploidy of the tumor needs to be determined [13]. One study reported serum

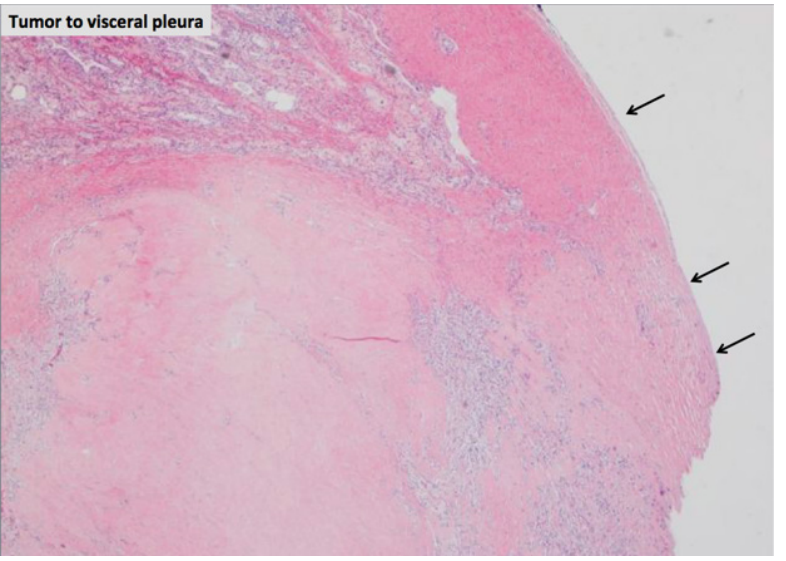

Figure 3. Low magnification image showing extension of the tumor extending to the visceral pleura indicated by the black arrows

hyaluronan as a surrogate marker that correlated with changes in the IMT [14]. This needs further investigation.

\section{Treatment}

Surgery is considered the mainstay of treatment. If complete resection is not possible, due to anatomic location or co-morbidities, then medical therapy in conjunction with radiation therapy could be considered.

\section{Surgery}

Complete surgical resection, when possible, is the best method for diagnosis and treatment [56, 61] (Fig. 4A, B). Lobectomy and pneumonectomy should be performed if required for complete cure. A recurrence rate of $8 \%$ was reported with a primarily surgical approach. However, it is unclear if the recurrence was local or distant [9].

\section{Bronchoscopy and endobronchial resection}

Rigid bronchoscopy and endobroncial resection (by surgical excision or laser) has been successful for IMTs confined to the trachea and smaller airways [71-74]. In some cases, this has been combined with use of steroids, with mixed results [75]. These patients should also be followed closely and may require more extensive surgery if persistence of the lesion is seen [76].

\section{Chemotherapy}

Chemotherapy is useful in cases of multifocal, invasive lesions or in cases of local recurrence [77]. Carboplatin and Paclitaxel have been reported to be useful in some cases [78], but this response does not appear to be generalizable to all cases [79]. 

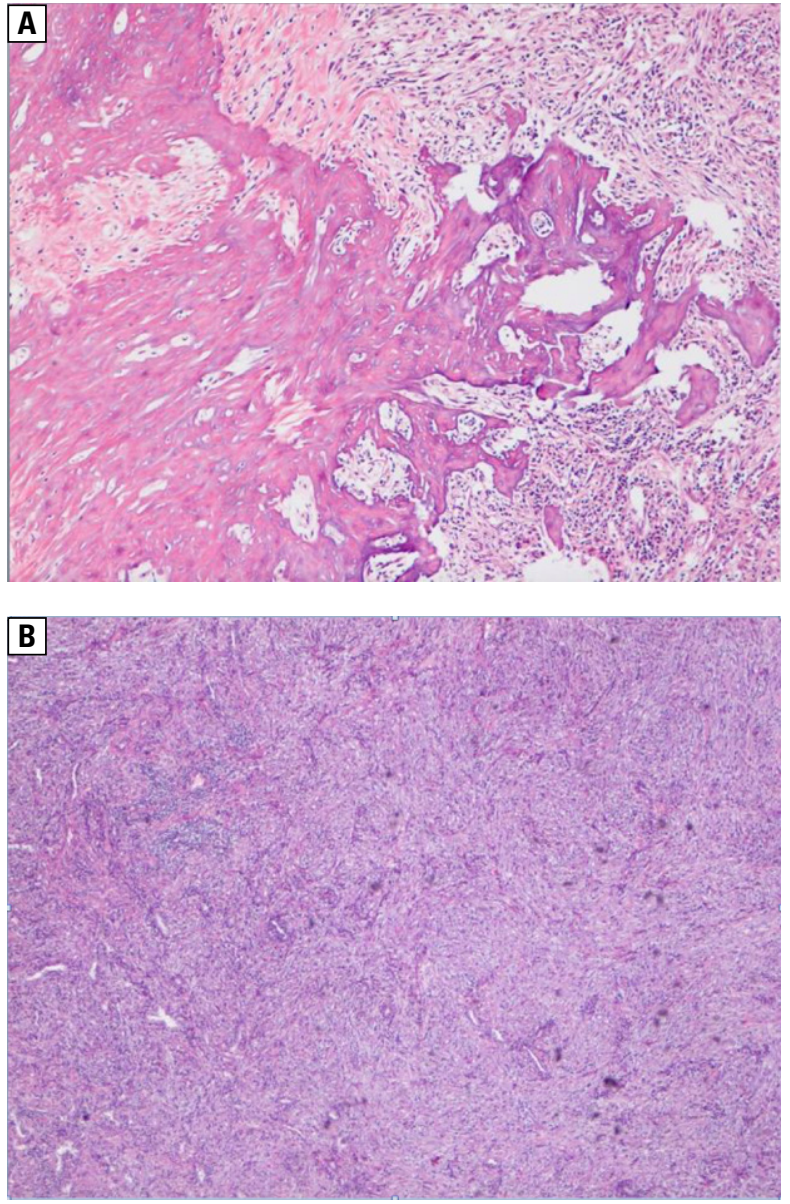

Figure 4A, B. Histopathology of the tumor demonstrating spindle cells

\section{Steroids}

The use of steroids for IMTs is controversial. They were initially recommended to reduce surrounding inflammation, particularly in CNS IMTs [9]. IMT response to steroid therapy [68, 80] and steroids along with antibiotics [10], has been well-documented. One case of recurrent IPT, 11 years after steroid therapy, responded to repeat steroid therapy [25]. Some believe that the cases of IPTs/IMTs that responded to steroids could be based on the fact that they are IgG4-related, and this needs to be confirmed with histopathology [81]. However, other studies have reported worsening of IMT with steroids [82, 83]. Moon et al. [83] reported aggravation of pulmonary and bone metastases, as evident by radiologic worsening on bone scan and CT scan, as well as increased fibroblastic cell proliferation in cultures, in the presence of dexamethasone. However, we need larger studies to make determination of the efficacy of steroids for IMTs.

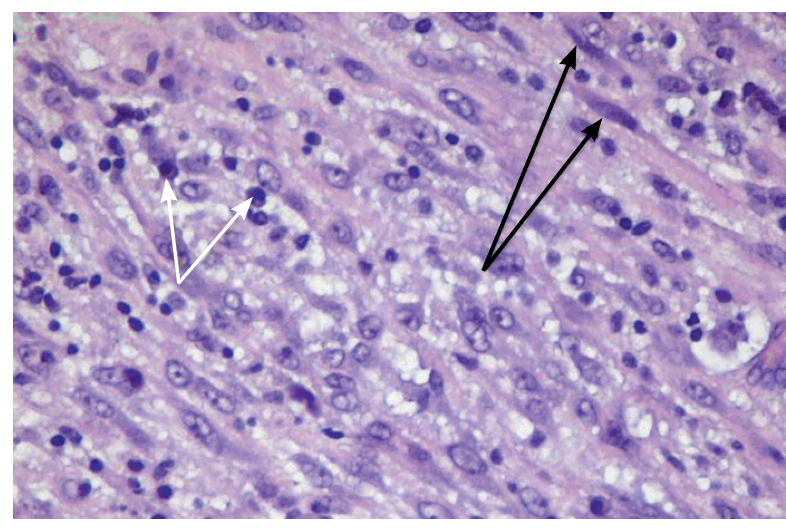

Figure 5. Black arrows represent myofibroblastic cells: spindle cells with long cytoplasmic processes which are characteristic in IMT. White arrows pointing to plasma cells with characteristic perinuclear cytoplasm which are often seen in IMT

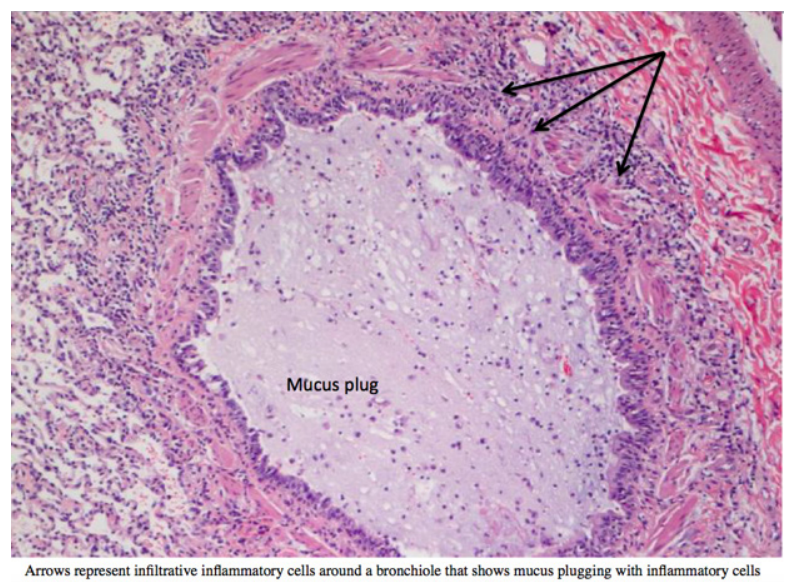

Figure 6. Arrows represent infiltrative inflammatory cells around a bronchiole that shows mucus plugging with inflammatory cells

\section{Non-steroidal anti-inflammatory drugs (NSAIDs)}

NSAIDs like Celecoxib have been used for some cases of histologically-proven IMT that are negative for ALK and ROS-1 mutations [22, 84]. This was based on the hypothesis that NSAIDs inhibit cyclo-oxygenase-2 (COX-2) enzyme and vascular endothelial growth factor (VEGF) signaling, thus interfering with angiogenesis. It was also observed that the level of ALK positivity in these cases did not correlate with the intensity of COX-2 or VEGF staining [85].

\section{ALK RTK inhibitors and ROS-1 TK inhibitors}

ALK RTK inhibitors (Crizotinib, Alectinib and Ceritinib) have been noted to be effective for 


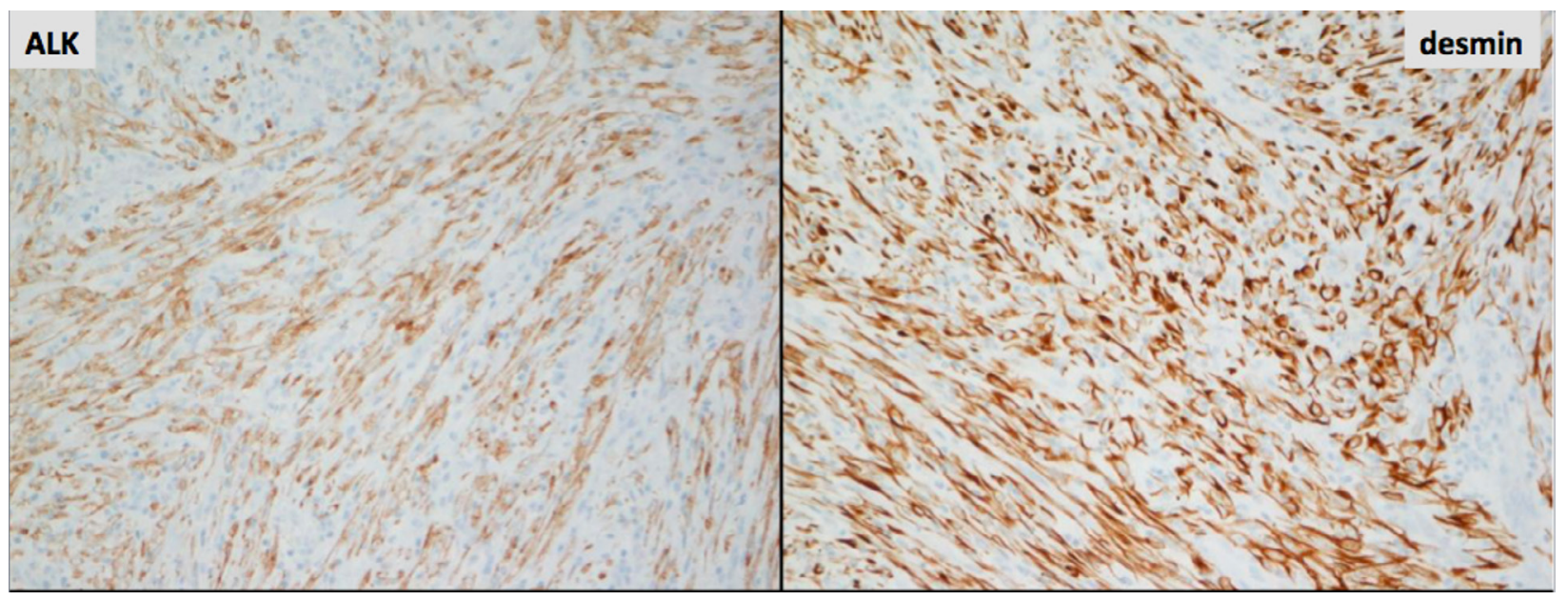

Figure 7. ALK and desmin staining of histopathologic sample

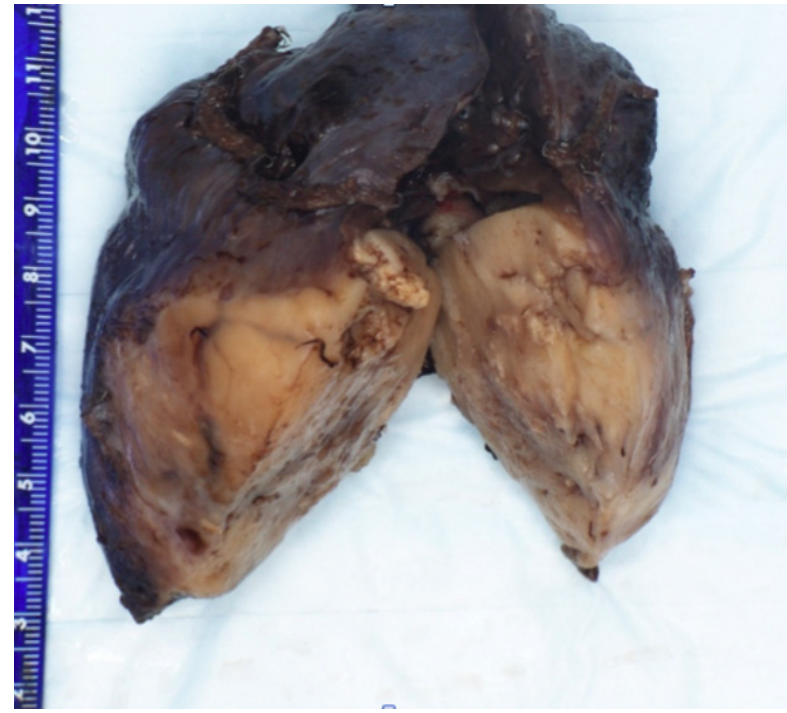

Figure 8. Gross pathology sample of a surgically removed IMT from a young adult

extra-pulmonary [86-88] and pulmonary IMTs [15]. They may be effective agents for patients with advanced or potentially unresectable ALK-rearranged IMTs, regardless of the location of the primary lesion [15]. Crizotinib has also proven to be effective in IMTs harboring ROS1 kinase fusions [21, 89].

\section{Radiation}

Radiation treatment has been shown to be of some benefit in pulmonary IMT [90, 91]. Failures of radiation therapy have, however, been reported suggesting that surgical excision should be primary therapy [81]. Radiation is typically reserved for palliation, to alleviate the mass effect of the IMT, or in conjunction with chemotherapy for cure in patients who are not amenable to resection [9]. As with chemotherapy, there is currently no evidence to support routine use of radiotherapy in patients who have complete resection.

\section{Prognosis}

Pulmonary IMT, if left untreated has shown an approximately $8 \%$ rate of growth on follow-up studies. In some cases of pulmonary IMT, spontaneous resolution has also been observed [92-94]. Prognosis is excellent after radical surgical excision, with 5-year survival rates greater than 91\% [5, 95-97]. Patients who underwent complete resection showed better survival rates [12]. One study reported a $60 \%$ recurrence rate in those receiving incomplete resection [5]. Interestingly, IPTs confined to the lung recurred less frequently than extra-pulmonary IPTs; but, if the IPT spread outside the lung, it recurred more frequently than extra-pulmonary IPTs that had spread to different organs [98].

A combination of cellular atypia, ganglion-like cells, TP53 expression, and aneuploidy may help to identify IMT with a more aggressive potential [4]. $A L K$-positive IMT is associated with better prognosis than $A L K$-negative IMT, as ALK-negative is associated with higher rate of metastasis and resistance to therapy [69]. Pulmonary IMT patients should have long-term follow up, due to the risk of recurrence and sarcomatous transformation [99]. Sarcomatous transformation has also been noted in extrapulmonary tumors [100].

\section{Conclusion}

Inflammatory myofibroblastic tumors (IMT) of the lung are a distinctive lesion composed of 
myofibroblastic spindle cells accompanied by an inflammatory infiltrate of plasma cells, lymphocytes, and eosinophils. IMTs may follow a benign course, be locally invasive or metastasize. Patients may be asymptomatic, or present with cough, hemoptysis, dyspnea, pleuritic pain, constitutional symptoms or pneumonia. Diagnosis is predominantly made using various imaging modalities and with histological confirmation. Genetic testing should also be conducted to assess for the possibility or targeted adjuvant therapies. Primary treatment of choice is surgical resection as well as chemotherapy. Though rare, IMT should be on the differential in patients who clinically present with signs and symptoms of lung mass.

\section{Acknowledgements}

Department of Pathology at Hofstra Northwell School of Medicine.

The authors declare no conflict of interest.

\section{References:}

1. Birch-Hirschfeld A. For the diagnosis and pathology of the orbital tumors [Zur Diagnostik und Pathologie der Orbitaltumoren]. Ber 32 Versamm Ophthal Ges Heidelberg. 1906; 32: 127-35.

2. Umiker WO, Iverson L. Postinflammatory tumors of the lung; report of four cases simulating xanthoma, fibroma, or plasma cell tumor. J Thorac Surg. 1954; 28(1): 55-63, indexed in Pubmed: 13175281.

3. Brunn $H$. Two interesting benign lung tumors of contradictory histopathology. J Thorac Surg. 1939; 9: 119-131.

4. Coffin CM. Inflammatory myofibroblastic tumour: World Health Organization classification of tumours. In: Fletcher CDM, Mertens F. ed. World Health Organization Classification of Tumours Pathology and Genetics of Tumours of Soft Tissue and Bone. IARC Press, Lyon 2002.

5. Cerfolio RJ, Allen MS, Nascimento AG, et al. Inflammatory pseudotumors of the lung. Ann Thorac Surg. 1999; 67(4): 933-936, indexed in Pubmed: 10320231.

6. Sakurai H, Hasegawa T, Watanabe Si, et al. Inflammatory myofibroblastic tumor of the lung. Eur J Cardiothorac Surg. 2004; 25(2): 155-159, indexed in Pubmed: 14747105.

7. Agrons GA, Rosado-de-Christenson ML, Kirejczyk WM, et al. Pulmonary inflammatory pseudotumor: radiologic features. Radiology. 1998; 206(2): 511-518, doi: 10.1148/radiology.206.2.9457206, indexed in Pubmed: 9457206.

8. Patankar T, Prasad S, Shenoy A, et al. Pulmonary inflammatory pseudotumour in children. Australas Radiol. 2000; 44(3): 318-320, indexed in Pubmed: 10974727.

9. Kovach SJ, Fischer AC, Katzman PJ, et al. Inflammatory myofibroblastic tumors. J Surg Oncol. 2006; 94(5): 385-391, doi: 10.1002/jso.20516, indexed in Pubmed: 16967468.

10. Shanmuganathan A, Dhungel K, Mahale A, et al. Inflammatory myofibroblastic tumor of lung (pseudotumor of the lung). Indian Journal of Radiology and Imaging. 2006; 16(2): 207-210, doi: 10.4103/0971-3026.29093.

11. Meis JM, Enzinger FM. Inflammatory fibrosarcoma of the mesentery and retroperitoneum. A tumor closely simulating inflammatory pseudotumor. Am J Surg Pathol. 1991; 15(12): 1146-1156, indexed in Pubmed: 1746682.

12. Melloni G, Carretta A, Ciriaco P, et al. Inflammatory pseudotumor of the lung in adults. Ann Thorac Surg. 2005; 79(2): 426-432, doi: 10.1016/j.athoracsur.2004.07.077, indexed in Pubmed: 15680808.
13. Biselli R, Ferlini C, Fattorossi A, et al. Inflammatory myofibroblastic tumor (inflammatory pseudotumor): DNA flow cytometric analysis of nine pediatric cases. Cancer. 1996; 77(4): 778-784, indexed in Pubmed: 8616772.

14. Ono A, Murakami H, Serizawa M, et al. Drastic initial response and subsequent response to two ALK inhibitors in a patient with a highly aggressive ALK-rearranged inflammatory myofibroblastic tumor arising in the pleural cavity. Lung Cancer. 2016; 99: 151-154, doi: 10.1016/j.lungcan.2016.07.002, indexed in Pubmed: 27565932.

15. Hallberg B, Palmer RH. Mechanistic insight into ALK receptor tyrosine kinase in human cancer biology. Nat Rev Cancer. 2013; 13(10): 685-700, doi: 10.1038/nrc3580, indexed in Pubmed: 24060861.

16. Cessna MH, Zhou H, Sanger WG, et al. Expression of ALK1 and p80 in inflammatory myofibroblastic tumor and its mesenchymal mimics: a study of 135 cases. Mod Pathol. 2002; 15(9): 931-938, doi: 10.1097/01.MP.0000026615.04130.1F, indexed in Pubmed: 12218210.

17. Griffin CA, Hawkins AL, Dvorak C, et al. Recurrent involvement of 2 p23 in inflammatory myofibroblastic tumors. Cancer Res. 1999; 59(12): 2776-2780, indexed in Pubmed: 10383129.

18. Chan JK, Cheuk W, Shimizu M. Anaplastic lymphoma kinase expression in inflammatory pseudotumors. Am J Surg Pathol. 2001; 25(6): 761-768, indexed in Pubmed: 11395553.

19. Minoo P, Wang HY. ALK-immunoreactive neoplasms. Int J Clin Exp Pathol. 2012; 5(5): 397-410, indexed in Pubmed: 22808292.

20. Lovly C, Horn L, Pao W. ROS1. My Cancer Genome. 2015 December 7, 2015. https://www.mycancergenome.org/content/ disease/lung-cancer/ros1/?tab $=0$ (1.10.2017).

21. Lovly CM, Gupta A, Lipson D, et al. Inflammatory myofibroblastic tumors harbor multiple potentially actionable kinase fusions. Cancer Discov. 2014; 4(8): 889-895, doi: 10.1158/21598290.CD-14-0377, indexed in Pubmed: 24875859.

22. Ghani S, Desai A, Pokharel S, et al. Pneumonectomy-Sparing NSAID Therapy for Pulmonary Inflammatory Myofibroblastic Tumor. J Thorac Oncol. 2015; 10(9): e89-e90, doi: 10.1097/ JTO.0000000000000574, indexed in Pubmed: 26291018.

23. Kazmierczak B, Dal Cin P, Sciot R, et al. Inflammatory myofibroblastic tumor with HMGIC rearrangement. Cancer Genet Cytogenet. 1999; 112(2): 156-160, indexed in Pubmed: 10686944.

24. Eichenlaub-Ritter U, Winking H. Nondisjunction, disturbances in spindle structure, and characteristics of chromosome alignment in maturing oocytes of mice heterozygous for Robertsonian translocations. Cytogenet Cell Genet. 1990; 54(1-2): 47-54, indexed in Pubmed: 2249474.

25. Treissman SP, Gillis DA, Lee CL, et al. Omental-mesenteric inflammatory pseudotumor. Cytogenetic demonstration of genetic changes and monoclonality in one tumor. Cancer. 1994; 73(5): 1433-1437, indexed in Pubmed: 8111710.

26. Kishi K, Fujii T, Kurosaki A, et al. Recurrence of inflammatory pseudotumor of the lung after eleven years of remission. Intern Med. 2009; 48(12): 1079-1083, indexed in Pubmed: 19525603.

27. Schweckendiek D, Inci I, Schneiter D, et al. Inflammatory Myofibroblastic Tumor of the Lung: Two Progressing Pulmonary Nodules in a 25-Year-Old Adult With a Moraxella catharalis Infection. Ann Thorac Surg. 2015; 100(6): e123-e124, doi: 10.1016/j. athoracsur.2015.06.111, indexed in Pubmed: 26652567.

28. Janigan DT, Marrie TJ. An inflammatory pseudotumor of the lung in Q fever pneumonia. N Engl J Med. 1983; 308(2): 8688, doi: 10.1056/NEJM198301133080207, indexed in Pubmed: 6847938.

29. Lipton JH, Fong TC, Gill MJ, et al. Q fever inflammatory pseudotumor of the lung. Chest. 1987; 92(4): 756-757, indexed in Pubmed: 3652767.

30. Polo MF, Mastrandrea S, Santoru L, et al. Pulmonary inflammatory pseudotumor due to Coxiella burnetii. Case report and literature review. Microbes Infect. 2015; 17(11-12): 795798, doi: 10.1016/j.micinf.2015.08.008, indexed in Pubmed: 26342254.

31. Evans J, Chan C, Gluch L, et al. Inflammatory pseudotumour secondary to actinomyces infection. Aust N Z J Surg. 1999; 69(6): 467-469, indexed in Pubmed: 10392897. 
32. Dweik RA, Goldfarb J, Alexander F, et al. Actinomycosis and plasma cell granuloma, coincidence or coexistence: patient report and review of the literature. Clin Pediatr (Phila). 1997; 36(4): 229-233, doi: 10.1177/000992289703600408, indexed in Pubmed: 9114995.

33. Schweigert M, Dubecz A, Beron M, et al. Pulmonary infections imitating lung cancer: clinical presentation and therapeutical approach. Ir J Med Sci. 2013; 182(1): 73-80, doi: 10.1007/ s11845-012-0831-8, indexed in Pubmed: 22592566.

34. Park SH, Choe GY, Kim CW, et al. Inflammatory pseudotumor of the lung in a child with mycoplasma pneumonia. J Korean Med Sci. 1990; 5(4): 213-223, doi: 10.3346/jkms.1990.5.4.213, indexed in Pubmed: 2129214.

35. Cheuk W, Woo PC, Yuen KY, et al. Intestinal inflammatory pseudotumour with regional lymph node involvement: identification of a new bacterium as the aetiological agent. J Pathol. 2000; 192(3): 289-292, doi: 10.1002/1096-9896(2000)9999:9999<::AID-PATH767>3.0. CO;2-F, indexed in Pubmed: 11054710.

36. Wood C, Nickoloff BJ, Todes-Taylor NR. Pseudotumor resulting from atypical mycobacterial infection: a "histoid" variety of Mycobacterium avium-intracellulare complex infection. Am J Clin Pathol. 1985; 83(4): 524-527, indexed in Pubmed: 2984921.

37. Arber DA, Kamel OW, van de Rijn M, et al. Frequent presence of the Epstein-Barr virus in inflammatory pseudotumor. Hum Pathol. 1995; 26(10): 1093-1098, indexed in Pubmed: 7557942.

38. Mergan F, Jaubert F, Sauvat F, et al. Inflammatory myofibroblastic tumor in children: clinical review with anaplastic lymphoma kinase, Epstein-Barr virus, and human herpesvirus 8 detection analysis. J Pediatr Surg. 2005; 40(10): 1581-1586, doi: 10.1016/j.jpedsurg.2005.06.021, indexed in Pubmed: 16226988.

39. Gómez-Román JJ, Sánchez-Velasco P, Ocejo-Vinyals G, et al. Presence of human herpesvirus-8 DNA sequences and overexpression of human IL-6 and cyclin D1 in inflammatory myofibroblastic tumor (inflammatory pseudotumor). Lab Invest. 2000; 80(7): 1121-1126, indexed in Pubmed: 10908158.

40. Siminovich M, Galluzzo L, López J, et al. Inflammatory myofibroblastic tumor of the lung in children: anaplastic lymphoma kinase (ALK) expression and clinico-pathological correlation. Pediatr Dev Pathol. 2012; 15(3): 179-186, doi: 10.2350/11-101105-OA.1, indexed in Pubmed: 22280150.

41. Shlopov BV, French SW. Inflammatory myofibroblastic tumor of the lung with unique histological pattern and association with Sjögren's disease and systemic lupus erythematosus. Exp Mol Pathol. 2011; 91(2): 509-514, doi: 10.1016/j. yexmp.2011.05.008, indexed in Pubmed: 21669196.

42. Chang Y, Horoupian DS, Lane B, et al. Inflammatory pseudotumor of the choroid plexus in Sjögren's disease. Neurosurgery. 1991; 29(2): 287-290, indexed in Pubmed: 1886672.

43. Hosokawa A, Takahashi H, Akaike J, et al. [A case of Sjögren's syndrome associated with inflammatory pseudotumor of the liver]. Nihon Rinsho Meneki Gakkai Kaishi. 1998; 21(5): 226-233, indexed in Pubmed: 11155596.

44. Eckstein RP, Hollings RM, Martin PA, et al. Pancreatic pseudotumor arising in association with Sjögren's syndrome. Pathology. 1995; 27(3): 284-288, indexed in Pubmed: 8532398.

45. Deshpande V, Zen Y, Chan JKc, et al. Consensus statement on the pathology of IgG4-related disease. Mod Pathol. 2012; 25(9): 1181-1192, doi: 10.1038/modpathol.2012.72, indexed in Pubmed: 22596100.

46. Chougule A, Bal A, Das A, et al. A Comparative Study of Inflammatory Myofibroblastic Tumors and Tumefactive IgG4-related Inflammatory Lesions: the Relevance of IgG4 Plasma Cells. Appl Immunohistochem Mol Morphol. 2016; 24(10): 721-728, doi: 10.1097/PAI.0000000000000252, indexed in Pubmed: 26469330.

47. Fujino H, Park YD, Uemura S, et al. An endobronchial inflammatory myofibroblastic tumor in a 10 -yr-old child after allogeneic hematopoietic cell transplantation. Pediatr Transplant. 2014; 18(5): E165-E168, doi: 10.1111/petr.12275, indexed in Pubmed: 24814936 .

48. Fangusaro J, Klopfenstein K, Groner J, et al. Inflammatory myofibroblastic tumor following hematopoietic stem cell transplantation: report of two pediatric cases. Bone Marrow
Transplant. 2004; 33(1): 103-107, doi: 10.1038/sj.bmt.1704292, indexed in Pubmed: 14647262.

49. Tsutsumi Y, Kanamori H, Kawamura T, et al. Inflammatory pseudotumor of the brain following hematopoietic stem cell transplantation. Bone Marrow Transplant. 2005; 35(11): 1123-1124, doi: 10.1038/sj.bmt.1704955, indexed in Pubmed: 15821770

50. Priebe-Richter C, Ivanyi P, Buer J, et al. Inflammatory pseudotumor of the lung following invasive aspergillosis in a patient with chronic graft-vs.-host disease. Eur J Haematol. 2005; 75(1): 68-72, doi: 10.1111/j.1600-0609.2005.00478.x, indexed in Pubmed: 15946314.

51. Lykavieris P, Fabre M, Waguet J, et al. Inflammatory pseudotumor after liver transplantation. J Pediatr Gastroenterol Nutr. 2000; 31(3): 309-312, indexed in Pubmed: 10997379.

52. Harel Z, Perl J, Herzenberg AM, et al. Inflammatory pseudotumor of the kidney allograft. Am J Kidney Dis. 2009; 54(3): 533-537, doi: 10.1053/j.ajkd.2009.01.272, indexed in Pubmed: 19376619.

53. Remberger K, Weiss M, Gokel JM, et al. [Inflammatory pseudotumor of the pancreas with persistent hyper-insulinemia and hypoglycemia following long-term pancreatic transplantation]. Verh Dtsch Ges Pathol. 1987; 71: 328-332, indexed in Pubmed: 3326337.

54. Huang YH, Zhong DJ, Tang J, et al. Inflammatory myofibroblastic tumor of the liver following renal transplantation. Ren Fail. 2012; 34(6): 789-791, doi: 10.3109/0886022X.2012.673446, indexed in Pubmed: 22681584.

55. Matsubara O, Tan-Liu NS, Kenney RM, et al. Inflammatory pseudotumors of the lung: progression from organizing pneumonia to fibrous histiocytoma or to plasma cell granuloma in 32 cases. Hum Pathol. 1988; 19(7): 807-814, indexed in Pubmed: 2841219.

56. Kim JH, Cho JH, Park MS, et al. Pulmonary inflammatory pseudotumor--a report of 28 cases. Korean J Intern Med. 2002; 17(4): 252-258, indexed in Pubmed: 12647641.

57. Coffin CM, Humphrey PA, Dehner LP. Extrapulmonary inflammatory myofibroblastic tumor: a clinical and pathological survey. Semin Diagn Pathol. 1998; 15(2): 85-101, indexed in Pubmed: 9606801.

58. Singh S, Dorfman SR, Nuctern JG, et al. Recurrent pneumonias secondary to an endobronchial inflammatory myofibroblastic tumor. Am J Respir Crit Care Med. 2013; 187(1): e1-e2, doi: 10.1164/rccm.201202-0305IM, indexed in Pubmed: 23281356

59. Wu J, Zhu H, Li K, et al. Imaging observations of pulmonary inflammatory myofibroblastic tumors in patients over 40 years old. Oncol Lett. 2015; 9(4): 1877-1884, doi: 10.3892/ ol.2015.2923, indexed in Pubmed: 25789060.

60. Narla LD, Newman B, Spottswood SS, et al. Inflammatory pseudotumor. Radiographics. 2003; 23(3): 719-729, doi: 10.1148/rg.233025073, indexed in Pubmed: 12740472

61. Karapolat S, Seyis KN, Ersoz S, et al. Lung Image: Inflammatory Myofibroblastic Tumor. Lung. 2017; 195(3): 387-388, doi: 10.1007/s00408-017-0002-9, indexed in Pubmed: 28391529.

62. Dhouib A, Barrazzone C, Reverdin A, et al. Inflammatory myofibroblastic tumor of the lung: a rare cause of atelectasis in children. Pediatr Radiol. 2013; 43(3): 381-384, doi: 10.1007/ s00247-012-2508-x, indexed in Pubmed: 23149650.

63. Dogan MS, Doganay S, Koc G, et al. Inflammatory Myofibroblastic Tumor of the Kidney and Bilateral Lung Nodules in a Child Mimicking Wilms Tumor With Lung Metastases. J Pediatr Hematol Oncol. 2015; 37(6): e390-e393, doi: 10.1097/ /MPH.0000000000000353, indexed in Pubmed: 26018807.

64. Carillo C, Anile M, De Giacomo T, et al. Bilateral simultaneous inflammatory myofibroblastic tumor of the lung with distant metastatic spread. Interact Cardiovasc Thorac Surg. 2011; 13(2): 246-247, doi: 10.1510/icvts.2011.271932, indexed in Pubmed: 21606052.

65. Oguz B, Ozcan HN, Omay B, et al. Imaging of childhood inflammatory myofibroblastic tumor. Pediatr Radiol. 2015; 45(11): 1672-1681, doi: 10.1007/s00247-015-3377-x, indexed in Pubmed: 26135643.

66. Alongi F, Bolognesi A, Samanes Gajate AM, et al. Inflammatory pseudotumor of mediastinum treated with tomotherapy and monitored with FDG-PET/CT: case report and literature review. Tumori. 2010; 96(2): 322-326, indexed in Pubmed: 20572593. 
67. Calabrese F, Zuin A, Brambilla E, et al. Pulmonary inflammatory myofibroblastic tumour with unusual octreoscan uptake: two reports. Eur Respir J. 2010; 35(2): 448-450, doi: 10.1183/09031936.00053609, indexed in Pubmed: 20123851.

68. Doski JJ, Priebe CJ, Driessnack M, et al. Corticosteroids in the management of unresected plasma cell granuloma (inflammatory pseudotumor) of the lung. J Pediatr Surg. 1991; 26(9): 1064-1066, indexed in Pubmed: 1941485.

69. Bhagat P, Bal A, Das A, et al. Pulmonary inflammatory myofibroblastic tumor and IgG4-related inflammatory pseudotumor: a diagnostic dilemma. Virchows Arch. 2013; 463(6): 743-747, doi: 10.1007/s00428-013-1493-2, indexed in Pubmed: 24100523.

70. Takeuchi K, Soda M, Togashi Y, et al. Pulmonary inflammatory myofibroblastic tumor expressing a novel fusion, PPFIBP1-ALK: reappraisal of anti-ALK immunohistochemistry as a tool for novel ALK fusion identification. Clin Cancer Res. 2011; 17(10): 3341-3348, doi: 10.1158/1078-0432.CCR-110063, indexed in Pubmed: 21430068.

71. Andrade FM, Abou-Mourad OM, Judice LF, et al. Endotracheal inflammatory pseudotumor: the role of interventional bronchoscopy. Ann Thorac Surg. 2010; 90(3): e36-e37, doi: 10.1016/j.athoracsur.2010.06.013, indexed in Pubmed: 20732473.

72. Ono Y, Miyoshi T, Inutsuka K, et al. [Inflammatory myofibroblastic tumor of the trachea; report of a case]. Kyobu Geka. 2006; 59(9): 871-875, indexed in Pubmed: 16922451.

73. Breen DP, Dubus JC, Chetaille B, et al. A rare cause of an endobronchial tumour in children: the role of interventional bronchoscopy in the diagnosis and treatment of tumours while preserving anatomy and lung function. Respiration. 2008; 76(4): 444-448, doi: 10.1159/000101718, indexed in Pubmed: 17429193.

74. Barker AP, Carter MJ, Matz LR, et al. Plasma-cell granuloma of the trachea. Med J Aust. 1987; 146(8): 443-445, indexed in Pubmed: 3614056.

75. Oztuna F, Pehlivanlar M, Abul Y, et al. Adult inflammatory myofibroblastic tumor of the trachea: case report and literature review. Respir Care. 2013; 58(7): e72-e76, doi: 10.4187/respcare.02198, indexed in Pubmed: 23258581.

76. Cerfolio RJ, Matthews TC. Resection of the entire left mainstem bronchus for an inflammatory pseudotumor. Ann Thorac Surg. 2005; 79(6): 2127-2128, doi: 10.1016/j.athoracsur.2003.11.041, indexed in Pubmed: 15919323.

77. Pinilla I, Herrero Y, Torres MI, et al. Myofibroblastic inflammatory tumor of the lung. Radiologia. 2007; 49(1): 53-55, indexed in Pubmed: 17397624.

78. Kubo N, Harada T, Anai S, et al. Carboplatin plus paclitaxel in the successful treatment of advanced inflammatory myofibroblastic tumor. Intern Med. 2012; 51(17): 2399-2401, indexed in Pubmed: 22975556.

79. Suetsugu S, Yamamoto H, Izumi M, et al. A case of rapidly growing inflammatory myofibroblastic tumor in the lung. Nihon Kokyuki Gakkai Zasshi. 2009; 47(12): 1156-1160, indexed in Pubmed: 20058697.

80. Shirakusa T, Kusano T, Motonaga R, et al. Plasma cell granuloma of the lung - resection and steroid therapy. Thorac Cardiovasc Surg. 1987; 35(3): 185-188, doi: 10.1055/s-2007-1020226, indexed in Pubmed: 2442840.

81. Tsuboi H, Inokuma S, Setoguchi K, et al. Inflammatory pseudotumors in multiple organs associated with elevated serum IgG4 level: recovery by only a small replacement dose of steroid. Intern Med. 2008; 47(12): 1139-1142, indexed in Pubmed: 18552474.

82. Panigada S, Sacco O, Girosi D, et al. Corticosteroids may favor proliferation of thoracic inflammatory myofibroblastic tumors. Pediatr Pulmonol. 2014; 49(3): E109-E111, doi: 10.1002/ ppul.22977, indexed in Pubmed: 24347285

83. Moon CHo, Yoon JHo, Kang GW, et al. A case of recurrent pulmonary inflammatory myofibroblastic tumor with aggressive metastasis after complete resection. Tuberc Respir Dis (Seoul).
2013; 75(4): 165-169, doi: 10.4046/trd.2013.75.4.165, indexed in Pubmed: 24265646.

84. Su W, Ko A, O'Connell T, et al. Treatment of pseudotumors with nonsteroidal antiinflammatory drugs. J Pediatr Surg. 2000; 35(11): 1635-1637, indexed in Pubmed: 11083441.

85. Applebaum H, Kieran MW, Cripe TP, et al. The rationale for nonsteroidal anti-inflammatory drug therapy for inflammatory myofibroblastic tumors: a Children's Oncology Group study. J Pediatr Surg. 2005; 40(6): 999-1003; discussion 1003, doi: 10.1016/j.jpedsurg.2005.03.016, indexed in Pubmed: 15991185.

86. Butrynski JE, D’Adamo DR, Hornick JL, et al. Crizotinib in ALK-rearranged inflammatory myofibroblastic tumor. N Engl J Med. 2010; 363(18): 1727-1733, doi: 10.1056/NEJMoa1007056, indexed in Pubmed: 20979472.

87. Kimbara S, Takeda K, Fukushima H, et al. A case report of epithelioid inflammatory myofibroblastic sarcoma with RANBP2-ALK fusion gene treated with the ALK inhibitor, crizotinib. Jpn J Clin Oncol. 2014; 44(9): 868-871, doi: 10.1093/jjco/ hyu069, indexed in Pubmed: 25028698.

88. Jacob SV, Reith JD, Kojima AY, et al. An Unusual Case of Systemic Inflammatory Myofibroblastic Tumor with Successful Treatment with ALK-Inhibitor. Case Rep Pathol. 2014; 2014: 470340, doi: 10.1155/2014/470340, indexed in Pubmed: 25045570 .

89. ShawOu SHI, Bang YJ, Camidge DR. Efficacy and safety of crizotinib in patients with advanced ROS1-rearranged non-small cell lung cancer (NSCLC). J Clin Oncol. 2013; 31: 8032.

90. Imperato JP, Folkman J, Sagerman RH, et al. Treatment of plasma cell granuloma of the lung with radiation therapy. A report of two cases and a review of the literature. Cancer. 1986; 57(11): 2127-2129, indexed in Pubmed: 3697912.

91. Hoover SV, Granston AS, Koch DF, et al. Plasma cell granuloma of the lung, response to radiation therapy: report of a single case. Cancer. 1977; 39(1): 123-125, indexed in Pubmed: 401674.

92. Mehta J, Desphande S, Stauffer JL, et al. Plasma cell granuloma of the lung: endobronchial presentation and absence of response to radiation therapy. South Med J. 1980; 73(9): 1198-1201, indexed in Pubmed: 7414377.

93. Berardi RS, Lee SS, Chen HP. Inflammatory pseudotumors of the lung. Surg Gynecol Obstet. 1983; 156(1): 89-96, indexed in Pubmed: 6336632.

94. Mandelbaum I, Brashear RE, Hull MT. Surgical treatment and course of pulmonary pseudotumor (plasma cell granuloma). J Thorac Cardiovasc Surg. 1981; 82(1): 77-82, indexed in Pubmed: 7242136 .

95. Ochs K, Hoksch B, Frey U, et al. Inflammatory myofibroblastic tumour of the lung in a five-year-old girl. Interact Cardiovasc Thorac Surg. 2010; 10(5): 805-806, doi: 10.1510/ icvts.2009.219089, indexed in Pubmed: 20139200.

96. Zhang Yi, Dong ZJ, Zhi XY, et al. Inflammatory myofibroblastic tumor in lung with osteopulmonary arthropathy. Chin Med J (Engl). 2009; 122(24): 3094-3096, indexed in Pubmed: 20137509.

97. Chen CK, Jan CI, Tsai JS, et al. Inflammatory myofibroblastic tumor of the lung--a case report. J Cardiothorac Surg. 2010; 5: 55, doi: 10.1186/1749-8090-5-55, indexed in Pubmed: 20646317

98. Janik JS, Janik JP, Lovell MA, et al. Recurrent inflammatory pseudotumors in children. J Pediatr Surg. 2003; 38(10): 14911495, indexed in Pubmed: 14577073.

99. Spencer H. The pulmonary plasma cell/histiocytoma complex. Histopathology. 1984; 8(6): 903-916, indexed in Pubmed: 6098549.

100.Coffin CM, Watterson J, Priest JR, et al. Extrapulmonary inflammatory myofibroblastic tumor (inflammatory pseudotumor). A clinicopathologic and immunohistochemical study of 84 cases. Am J Surg Pathol. 1995; 19(8): 859-872, indexed in Pubmed: 7611533. 